\title{
Estimation of the Restrained Strains and Self-stresses under Two-way Restraint Conditions
}

\author{
Volha Sannikava*, Viktar Tur
}

Brest State Technical University, Faculty of Civil Engineering

Moskovskaya 267, 224017, Brest, Republic of Belarus

*Corresponding author: volhasannikava@list.ru

Гross

Models for the restrained expansion strains under two-way restraint conditions both with their advantages and disadvantages are presented. An implementation of the modified strains development model (MSDM) for the assessment of the two-way restrained expansion strains is proposed. The reliability of the proposed model for the two-way restraint conditions is confirmed by the experimental results based on the tests of the expansive concrete plane specimens with the mesh reinforcement in the mid-depth of the cross section.

Keywords: design model, expansive concrete, restrained expansion strains, two-way restraint conditions.

As was shown in Semianiuk et al. 2017, the development of concrete technologies in the last decades has opened the door to extended use of the High performance Concrete (HPC). Shrinkage strains perform the most considerable problem of practical application of the High strength and High performance concretes because of inducing the cracks formation at early age that makes worse the serviceability performance of concrete structures. Shrinkage processes are typical of any concrete system and depend on many factors such as type of cement, type of mineral admixtures, water-cement ratio and volume concentration of aggregate (Tazawa et al. 2000). Many studies have proved the effectiveness of the expansive concretes in the compensating of shrinkage (Tanimura et al. 2007) as well as in realization of the chemical prestressing of the structures (Mikhailov and Litver 1974). 1974). In general, as was shown in Semianiuk et al. 2017, models for the estimation of the restrained strains and self-stresses in expansive concrete at early age are based on one of two basic concepts: conservation law of chemical energy or initial strain calculation.

To design self-stressed concrete structures it's necessary to take into account the initial stressstrain state caused by the concrete expansion under restraint conditions. The dependence of restrained strains from the reinforcement arrangement (uniaxial, biaxial, triaxial), stiffness characteristics of restraint, curing conditions is confirmed by numerous investigations of self-stressed elements (Litver and Petukhov 1984, Litver and Sabajeva 1984, Marchuk 2002, Mikhailov and Gershvald 1984, Mikhailov and Litver 1974,). It should be noticed that because of the features of the expansive concrete process under two-way restraint conditions the self-stressed concrete ob-

\section{Introduction}

Estimation of the Restrained Strains and Self-stresses under Two-way Restraint Conditions

Received 2017/09/18

Accepted after revision 2017/11/21

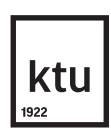

Journal of Sustainable Architecture and Civil Engineering Vol. 3 / No. 20 / 2017 pp. $75-86$

DOI 10.5755/j01.sace.20.3.19082 (c) Kaunas University of Technology 
tain more solid structure than that of under one-way restraint conditions. Therefore the shrinkage strains become less apparent for the self-stressed elements under two-way restraint conditions. Moreover these elements made with high expansion energy capacity concrete perform the extreme values of self-stressing in comparison with the element under uniaxial restraint (Litver and Sabajeva 1984).

Consequently, design model for the numerical determination of the restrained strains and self-stresses at the expansive stage of the concrete should be done in favour of that which could adequately reproduce chemical, physical and mechanical processes during the self-stressing concrete expansion under various design and technological factors.

Methods for estimation of the restrained strains and stresses in the expansive concrete at early age

\section{Models of estimation the restrained expansion strains and self-stresses at the expansion stage of the concrete under two-way restraint conditions}

The following models for the evaluation of the restrained expansion strains in the reinforcement for elements under two-way restraint conditions have been suggested.

Model 1. In accordance with the TCP Codes (2010), the strain in the center of gravity of reinforcement at the section by the time of the expansive concrete stabilization is expressed as:

$$
\varepsilon_{s . C E}=\frac{1}{\rho_{l} \cdot E_{s}} f_{C E . d} \cdot k_{s} \cdot k_{\rho} \cdot k_{e} \cdot k_{w} \cdot k_{0}
$$

where $f_{C E . d}$ - design self-stress of the concrete that is taken from the table 6, 7 TCP Codes (2010) depending on the self-stressing grade of the expansive concrete; $\rho_{l}-$ total cross sectional reinforcement ratio; $E_{s}$ - Young's modulus of the reinforcement; $k_{s}$ - factor that depends on the reinforcement arrangement in plane and equals 1,2 for the biaxial reinforcement arrangement in the concrete element; $k_{\rho}$ - factor that depends on the total cross sectional reinforcement ratio for the given direction $\left(\rho_{l}\right)$ and is defined as follows:

$$
k_{\rho}=\sqrt{\frac{1,57 \cdot \rho_{l}}{0,0057+\rho_{l}}}
$$

$k_{e}$ - factor that represents the influence of the reinforcement eccentricity; $k_{w}$ - factor that counts the influence of the expansive concrete initial compressive strength at the

beginning of moisture curing; $k_{0}$ - factor that counts self-stressed element curing conditions at the expansion stage of the concrete.

From this model it could be seen that two-way axial restraint conditions are considered only by the factor $k_{s}$ from the Eq. (1).

Model 2. According to the experimental data obtained by Marchuk (2002) the empirical expressions which consider the interference of the restraint in the principal axes directions on the restrained expansion strains are received:

- in the direction $x$

$$
\begin{cases}\varepsilon_{C E . x}=\left(0,98+16 \cdot \rho_{l y}-12 \cdot \rho_{l x}\right) \cdot \varepsilon_{C E . x .0}, & \text { if } \rho_{l x} \leq \rho_{l y} \\ \varepsilon_{C E . x}=\left(0,98+16 \cdot \rho_{l x}-12 \cdot \rho_{l y}\right) \cdot \varepsilon_{C E . x .0}, & \text { if } \rho_{l x}>\rho_{l y}\end{cases}
$$

in the direction $y$

$$
\begin{cases}\varepsilon_{C E . y}=\left(0,98+16 \cdot \rho_{l x}-12 \cdot \rho_{l y}\right) \cdot \varepsilon_{C E . y .0}, & \text { if } \rho_{l y} \leq \rho_{l x} \\ \varepsilon_{C E . y}=\left(0,98+16 \cdot \rho_{l y}-12 \cdot \rho_{l x}\right) \cdot \varepsilon_{C E . y .0}, & \text { if } \rho_{l y}>\rho_{l x}\end{cases}
$$

where $\varepsilon_{C E . x .0}$ and $\varepsilon_{C E . y .0}$ - restrained expansion strains of the expansive concrete in the direction $x$ without considering the restraint in the direction $y$ and otherwise in the direction $y$ without considering the restraint in the direction $x$ respectively: 


$$
\varepsilon_{C E . x .0}=\frac{f_{C E . d} \cdot k_{\rho x}}{\rho_{l x} \cdot E_{s}} ; \quad \varepsilon_{C E . y .0}=\frac{f_{C E . d} \cdot k_{\rho y}}{\rho_{l y} \cdot E_{s}}
$$

where $\rho_{l x}$ and $\rho_{l y}$ - reinforcement ratio in the directions $x$ and $y$ respectively; $f_{C E . d}, E_{s^{\prime}} k_{\mathrm{\rho}}-$ as in the Eq. (1).

As seen from the above models 1 and 2 , the components $\left(0,98+16 \cdot \rho_{l x}-12 \cdot \rho_{l v}\right)$ and $\left(0,98+16 \cdot \rho_{l y}-12 \cdot \rho_{l x}\right)$ from the Eqs. (3) and (4) are, in fact, the refined values of the factor $k_{s}$ from the Eq. (1).

Model 3. In the work Litver and Petukhov (1984) for the symmetrical reinforced plane self-stressed elements with the reinforcement ratio $\rho_{l}$ the self-stress is defined in accordance with:

$$
\sigma_{C E .2}=f_{C E . d .2} \cdot \rho_{l}^{0,702-0,0278 \cdot f_{C E . d .2}}
$$

where $f_{C E . d .2}$ - the value of the self-stress which is defined in the dynamometrical rings with stiffness equals $\rho_{l}=1 \%$.

Model 4. In the case of nonsymmetrical restraint in two directions in the paper Mikhailov and Gershvald (1984) the system of equations is used:

$$
\left\{\begin{array}{l}
\left(\frac{A}{\sigma_{C E . x}+C}\right)^{1 / n}-\lambda\left(\frac{A}{\sigma_{C E . y}+C}\right)^{1 / n}-B(1-\lambda)-\frac{\sigma_{C E . x}}{k_{x}}=0 \\
\left(\frac{A}{\sigma_{C E . y}+C}\right)^{1 / n}-\lambda\left(\frac{A}{\sigma_{C E . x}+C}\right)^{1 / n}-B(1-\lambda)-\frac{\sigma_{C E . y}}{k_{y}}=0
\end{array}\right.
$$

where $\sigma_{C E . x}$ and $\sigma_{C E . y}$ - self-stresses in the concrete in the direction $x$ and $y$ respectively; A, B, C empirical coefficients; $k_{x}=\rho_{l x} \cdot E_{s} \cdot 10^{-2}, k_{y}=\rho_{l y} \cdot E_{s} \cdot 10^{-2}$ - stiffness characteristics of restraint in the direction $x$ and $y$ respectively; $\lambda$ - Poisson's ratio of the expansive concrete at early age that is accepted to be equal to 0,46..0,48 in accordance with Mikhailov and Gershvald (1984).

It should be mentioned that all proposed design models of defining the stress-strain parameters of self-stressed elements under two-way restraint conditions have some significant disadvantages. First, all formulas contain either the empirical factors or expressions which are restricted by research conditions. Second, no one formula counts the early age expansive concrete behavior as well as the contribution of elastic and plastic (creep) concrete strains on the restrained strains. As in the researches Tsuji (1984) these models are based on the energy conservation law and allow to calculate the self-stresses or restrained expansion strains only by the end of the expansive concrete stabilization. It's significant that at practical application of listed models some contradictions have been evolved (TCP Code 2010) as they are being caused by different correlations of the free expansion strains and the standard self-stressing grade of the expansive concrete $f_{C E . d}$.

Model 5. A more advanced finite element method along with a practical calculation method based on the beam theory considers the mentioned disadvantages (Ito et al. 2004). In accordance with this model for the self-stressed reinforced concrete elements in the case of the uniaxial reinforcement arrangement the strain in the $\mathrm{x}$-direction at the $\mathrm{i}$-th time interval is calculated by:

$$
\varepsilon_{x}\left(t_{i+1 / 2}\right)=\sum_{j=1}^{i}\left[\left(\Delta \sigma_{x, c}\right)_{j} \cdot J\left(t_{i+1 / 2}, t_{j}\right)\right]+\varepsilon_{x, \Delta T, a s, d s}\left(t_{i+1 / 2,2} t_{1 / 2}\right)
$$

where $\left(\Delta \sigma_{x, c}\right)_{j}$-incremental self-stress in the x-direction at the j-th time interval; $\varepsilon_{x, \Delta T, a s, d s}\left(t_{i+1 / 2,2} t_{1 / 2}\right)$ difference of the free strain due to the temperature change and shrinkage or expansion of the 
expansive concrete in the $\mathrm{x}$-direction from the time interval $t_{1 / 2}$ to the $t_{i+1 / 2} ; J\left(t_{i+1 / 2}, t_{j}\right)$-creep compliance function which is defined by:

$$
J\left(t_{i+1 / 2}, t_{j}\right)=\frac{1}{E_{c}\left(t_{j}\right)}+\frac{\varphi\left(t_{i+1 / 2}, t_{j}\right)}{E_{c, 28}}
$$

temperature adjusted concrete age: $\varphi\left(t_{i+1 / 2}, t\right)$ - creep coefficient of the expansive concrete at $t_{i+1 / 2}$ days under constant self-stress applied at $t_{j}$ days.

The Young's modulus of the expansive concrete at early age is calculated in accordance with the Eurocode 2 model (2004):

$$
E_{c}(t)=E_{c, 28} \cdot \exp \left(s\left(1-\left(\frac{t_{e, 28}-a}{t-a}\right)^{0,5}\right)\right)
$$

The temperature adjusted concrete age at $t$ days is determined by the equation (Ito et al. 2004):

$$
t=\sum_{i=1}^{n} \Delta t_{i} \cdot \exp \left[13,65-\frac{4000}{273+T\left(\Delta t_{i}\right) / T_{0}}\right]
$$

where $\Delta t_{i}$ - number of days where a temperature $T\left({ }^{\circ} \mathrm{C}\right)$ prevails; $T\left(\Delta t_{i}\right)-$ temperature in $\left[{ }^{\circ} \mathrm{C}\right]$ during the time period $\Delta t_{i}$; $T_{0}=1^{\circ} \mathrm{C}$.

The creep coefficient $\varphi\left(t, t_{0}\right)$ for the expansive concrete at early age is defined in accordance with fib Model Code (2010) by the equation:

$$
\varphi\left(t, t_{0}\right)=\varphi_{0} \cdot \beta_{c}\left(t, t_{0}\right)
$$

where $\varphi_{0}-$ notional creep coefficient that is estimated with regard to the relative Young's modulus $E_{c}\left(t_{0}\right) / E_{c, 28}$ (the ratio of the

Young's modulus of the expansive concrete at $t_{0}$ to that of the expansive concrete at 28 days in the temperature adjusted concrete age) by the expression suggested in the paper Ito et al. (2004):

$$
\varphi_{0}=5,31 \cdot\left(E_{c}\left(t_{0}\right) / E_{c, 28}-1\right)^{2}+1,11
$$

Model Code (2010) by the equation:

$$
\beta_{c}\left(t, t_{0}\right)=\left[\frac{t-t_{0}}{\beta_{i}+\left(t-t_{0}\right)}\right]^{0,3}
$$

$\beta_{c}\left(t, t_{0}\right)$ - coefficient to describe the development of creep with time after loading and it is calculated in accordance with fib

where $t$ - temperature adjusted concrete age; $t_{0}$ - temperature adjusted concrete age of loading age; $\beta_{i}$ - coefficient representing the effect of loading age on the rate of creep development and it is defined with

regard to the relative Young's modulus $E_{c}(t) / E_{c, 28}$ (the ratio of the Young's modulus of the expansive concrete at $t$ to that of the expansive concrete at 28 days in the temperature adjusted concrete age) by the expression suggested in the paper Ito et al. (2004):

$$
\left\{\begin{array}{l}
\beta_{i}=0,000001, \text { if } 0 \leq E_{c}(t) / E_{c, 28}<0,346 \\
\beta_{i}=40,5 \cdot\left(\frac{E_{c}(t)}{E_{c, 28}}-0,346\right)+0,485, \text { if } 0,346 \leq E_{c}(t) / E_{c, 28}<1,0
\end{array}\right.
$$


The difference of strain at i-th time interval and (i-1)-th time interval is obtained:

$$
\begin{aligned}
& \left(\Delta \varepsilon_{x, c}\right)_{i}=\varepsilon_{x}\left(t_{i+1 / 2}\right)-\varepsilon_{x}\left(t_{(i-1)+1 / 2}\right)= \\
& \left(\Delta \sigma_{x, c}\right)_{i} \cdot J\left(t_{i+1 / 2}, t_{i}\right)+\sum_{j=1}^{i-1}\left[\left(\Delta \sigma_{x, c}\right)_{j} \cdot \frac{\Delta \varphi\left(t_{i}, t_{j}\right)}{E_{c, 28}}\right]+\left(\Delta \varepsilon_{x, \Delta T, a s, d s}\right)_{i}
\end{aligned}
$$

with:

$$
\Delta \varphi\left(t_{i}, t_{j}\right)=\varphi\left(t_{i+1 / 2}, t_{j}\right)-\varphi\left(t_{(i-1)+1 / 2}, t_{j}\right)
$$

Thus the incremental stress in the x-direction at the i-th time interval is calculated as follow:

$$
\left(\Delta \sigma_{x, c}\right)_{i}=\frac{E_{c}\left(t_{i}\right)}{1+\frac{E_{c}\left(t_{i}\right)}{E_{c, 28}} \cdot \varphi\left(t_{i+1 / 2}, t_{i}\right)}\left(\left(\Delta \varepsilon_{x, c}\right)_{i}-\sum_{j=1}^{i-1}\left[\frac{\left(\Delta \sigma_{x, c}\right)_{j}}{E_{c, 28}} \cdot \Delta \varphi\left(t_{i}, t_{j}\right)\right]-\left(\Delta \varepsilon_{x, \Delta T, a s, d s}\right)_{i}\right)
$$

where $\varphi\left(t_{i+1 / 2}, t_{i}\right)$ - creep coefficient of the expansive concrete at $t_{i+1 / 2}$ days under constant selfstress applied at $t_{i}$ days; $\left(\Delta \varepsilon_{x, \Delta T, a s, d s}\right)_{i}$ - incremental free strain due to the temperature change and shrinkage or expansion of the expansive concrete in the $\mathrm{x}$-direction at the i-th time interval; $\Delta \varphi\left(t_{i}, t_{j}\right)$ - incremental creep coefficient of the expansive concrete at the i-th time interval under constant self-stress applied at the $\mathrm{j}$-th time interval.

Being the most rational today, the deformation model 5 can be used for the self-stressed reinforced concrete elements under arbitrary restrained conditions and allows to evaluate the stressstrain relationship of the self-stressed elements from the early age to the concrete expansion stabilization. If the free strain function and the incremental self-stress at (i-1)-th time interval are known, the incremental self-stresses and correspondingly the incremental restrained expansion strains at $\mathrm{i}$-th time interval in the $\mathrm{x}$-direction are calculated.

However, the presented above model has got one important contradiction, what has been confirmed by own experimental data. As noticed in the researches Tur and Semianiuk (2016) and Semianiuk et al. (2017) the expansion of the expansive concrete element at the elementary i-th time interval occurs in the presence of the cumulative force induced by the restraint at the end of the (i-1)-th time interval (Fig. 1).

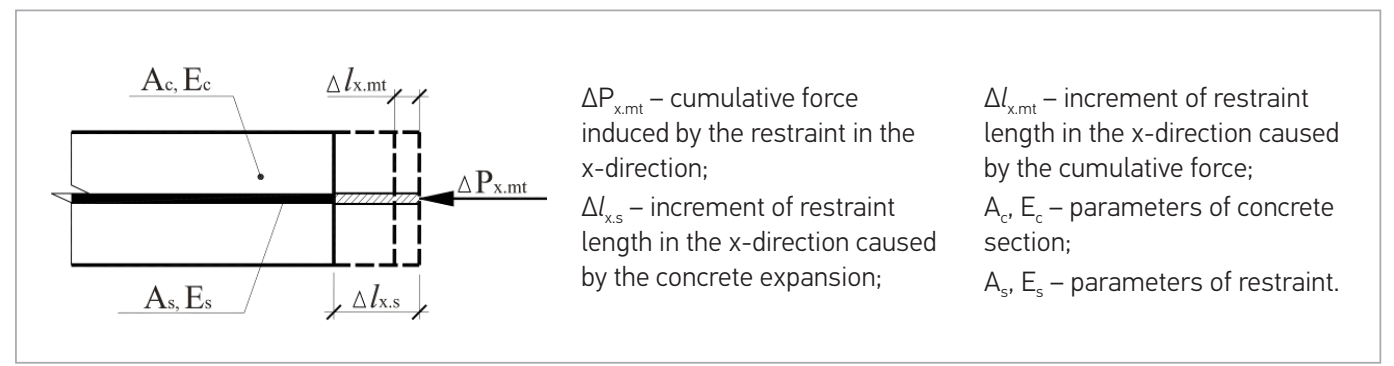

Fig. 1

Scheme of the addition cumulative force action

Thus, the main theses of the deformation model (model 5) modified by taking into account the additional cumulative force induced by the restraint have allowed to formulate the design model for self-stressed elements under two-way restraint conditions both for symmetrical and nonsymmetrical restraint in two directions. 


\section{Implementation of the MSDM-model for the assessment of the two-way restrained strains}

The general theoretical background of the modified early age strains development model (MSDM) for concrete with high expansion energy capacity in the case of the uniaxial reinforcement arrangement has been presented in the works Tur and Semianiuk (2016) and Semianiuk et al. (2017). It should be noticed that because of the bond conditions the expansive concrete and the reinforcement deform compatibly:

$$
\left(\Delta \sigma_{x, c}\right)_{i}=\left(\Delta \varepsilon_{x, s}\right)_{i} \cdot E_{s} \cdot \rho_{x, l}
$$

In the present investigations, considering the additional cumulative force, the Eq. (9) and the law of signs (expansive strains are taken with "plus", shrinkage strains are taken with "minus"), the incremental restrained expansion strains in the x-direction at the i-th time interval are calculated as follows:

$$
\left(\Delta \varepsilon_{x, s}\right)_{i}=\frac{D}{D+1}\left(\left(\Delta \varepsilon_{c f}\right)_{i}-\sum_{j=1}^{i-1}\left[\left(\Delta \sigma_{x, c}\right)_{j} \cdot \frac{\Delta \varphi\left(t_{i}, t_{j}\right)}{E_{c, 28}}\right]\right)-\sum_{j=1}^{i-1}\left(\Delta \varepsilon_{x, s}\right)_{j} \cdot \rho_{x, l} \cdot \frac{E_{s}}{E_{c}\left(t_{(i-1)+1 / 2}\right)}
$$

$$
D=\frac{E_{c}\left(t_{i}\right)}{\left(1+\frac{E_{c}\left(t_{i}\right)}{E_{c, 28}} \cdot \varphi\left(t_{i+1 / 2}, t_{i}\right)\right) \cdot E_{s} \cdot \rho_{x, l}}
$$

where $\left(\Delta \varepsilon_{c f}\right)_{i}$ - incremental free expansion strain at the i-th time interval; $\sum_{j=1}^{i-1}\left(\Delta \varepsilon_{x, s}\right)_{j}-$ resultant restrained expansion strains from the cumulative force at the end of (i-1)-th time interval of the concrete expansion; $E_{c}\left(t_{(i-1)+1 / 2}\right)$ - Young's modulus of the expansive concrete at the end of (i-1)-th time interval. The details of the Eq. (10) are presented in the work Tur et al. (2016).

In the case of two-way restraint conditions the stresses in the principal axes directions are connected by means of Poisson's ratio $(\mu)$. There are two points of view concerning the Poisson's ratio of the early age concrete. Some researchers (Oluokun et al. 1991, Truman et al. 1991) regard that one remains constant during expansion stage whereas others (Mikhailov and Gershvald 1984, Byfors 1980, De Schutter and Taerwe 1996) have proved experimentally the evolution of the Poisson's ratio during the hydration. In the present study the Poisson's ratio of the early age concrete is taken $\mu=0,47$ according to Mikhailov and Gershvald (1984).

Thus, for the two-way restraint conditions the incremental restrained expansion strains at the $i$-th time interval in the principal axes directions are calculated by:

$$
\left\{\begin{array}{l}
\left(\Delta \varepsilon_{x, s}\right)_{i}=\frac{D}{D+1}\left(\left(\Delta \varepsilon_{c f}\right)_{i}-\sum_{j=1}^{i-1}\left[\left(\Delta \sigma_{x, c}\right)_{j} \cdot \frac{\Delta \varphi\left(t_{i}, t_{j}\right)}{E_{c, 28}}\right]\right)-\sum_{j=1}^{i-1}\left(\Delta \varepsilon_{x, s}\right)_{j} \cdot \rho_{x, l} \cdot \frac{E_{x, s}}{E_{c}\left(t_{(i-1)+1 / 2}\right)} \\
\left(\Delta \varepsilon_{y, s}\right)_{i}=\frac{D}{D+1}\left(\left(\Delta \varepsilon_{c f}\right)_{i}-\sum_{j=1}^{i-1}\left[\left(\Delta \sigma_{y, c}\right)_{j} \cdot \frac{\Delta \varphi\left(t_{i}, t_{j}\right)}{E_{c, 28}}\right]\right)-\sum_{j=1}^{i-1}\left(\Delta \varepsilon_{y, s}\right)_{j} \cdot \rho_{y, l} \cdot \frac{E_{y, s}}{E_{c}\left(t_{(i-1)+1 / 2}\right)}
\end{array}\right.
$$

The incremental self-stresses at the i-th time interval in the principal axes directions are obtained as follows:

$$
\left\{\begin{array}{l}
\left(\Delta \sigma_{x}\right)_{i}=\left(\Delta \varepsilon_{x, s}\right)_{i} \cdot E_{x, s} \cdot \rho_{x, l}-\mu \cdot\left(\left(\Delta \varepsilon_{y, s}\right)_{i} \cdot E_{y, s} \cdot \rho_{y, l}\right) \\
\left(\Delta \sigma_{y}\right)_{i}=\left(\Delta \varepsilon_{y, s}\right)_{i} \cdot E_{y, s} \cdot \rho_{y, l}-\mu \cdot\left(\left(\Delta \varepsilon_{x, s}\right)_{i} \cdot E_{x, s} \cdot \rho_{x, l}\right)
\end{array}\right.
$$


The total self-stresses and restrained expansion strains in the principal axes directions at given time interval are defined by:

$$
\left\{\begin{array}{l}
\left(\sigma_{x}\right)_{i}=\left(\sigma_{x}\right)_{i-1}+\left(\Delta \sigma_{x}\right)_{i} \\
\left(\sigma_{y}\right)_{i}=\left(\sigma_{y}\right)_{i-1}+\left(\Delta \sigma_{y}\right)_{i}
\end{array} ;\left\{\begin{array}{l}
\left(\varepsilon_{x, s}\right)_{i}=\left(\varepsilon_{x, s}\right)_{i-1}+\left(\Delta \varepsilon_{x, s}\right)_{i} \\
\left(\varepsilon_{y, s}\right)_{i}=\left(\varepsilon_{y, s}\right)_{i-1}+\left(\Delta \varepsilon_{y, s}\right)_{i}
\end{array}\right.\right.
$$

The iterative calculation continues until the end of the expansive concrete stabilization period.

\section{Experimental investigations}

For the verification of the proposed model for the restrained expansion strains estimation at the expansion stage of the concrete under two-way restraint conditions the experimental investigations were conducted.

The present investigations were carried out based on the three series of the expansive concrete plane specimens with the mesh reinforcement in the mid-depth of the cross section (Fig. 2). The restraint rate in the principal axes directions was taken as the variable parameter of samples.
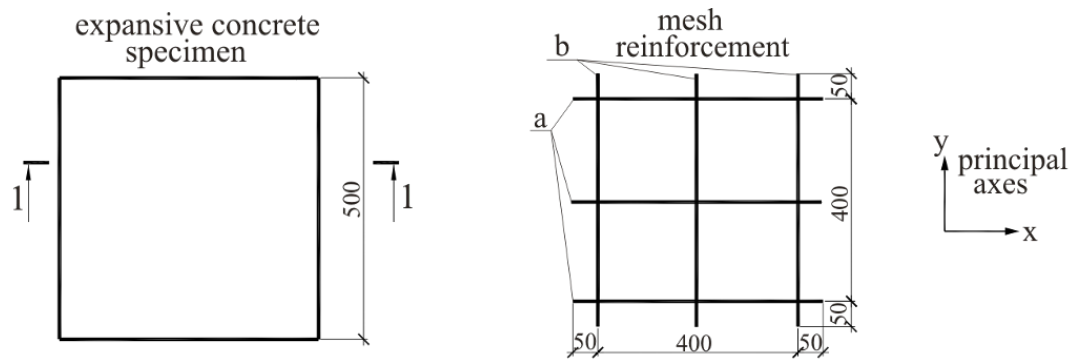

Fig. 2

Details of the experimental specimens

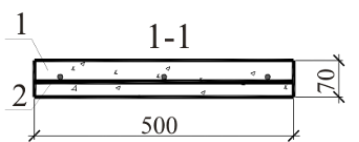

1 - expansive concrete,

2 - mesh reinforcement

\begin{tabular}{c|c|c}
\hline series & $\mathrm{a}$ & $\mathrm{b}$ \\
\hline $\mathrm{I}$ & $3 \emptyset 12 \mathrm{~mm}$ & $3 \emptyset 5 \mathrm{~mm}$ \\
\hline$I I$ & $3 \emptyset 12 \mathrm{~mm}$ & $3 \emptyset 12 \mathrm{~mm}$ \\
\hline$I I I$ & $3 \varnothing 5 \mathrm{~mm}$ & $3 \emptyset 5 \mathrm{~mm}$ \\
\hline
\end{tabular}

Geometry and reinforcement characteristics of the expansive concrete specimens are listed in the Table 1. The view of the mold with mesh reinforcement and the specimen after casting is presented in the Fig. 3.

\begin{tabular}{|c|c|c|c|c|c|c|}
\hline \multirow[b]{2}{*}{ series } & \multirow[b]{2}{*}{$\begin{array}{l}\text { specimen } \\
\text { marking }\end{array}$} & \multirow{2}{*}{$\begin{array}{l}\text { specimen } \\
\text { geometry, } \\
\text { mm, bxlxh }\end{array}$} & \multicolumn{2}{|c|}{$\mathrm{x}$-direction } & \multicolumn{2}{|c|}{$y$-direction } \\
\hline & & & $A_{s x}, m^{2}$ & $\begin{array}{l}\text { reinforcement } \\
\text { ratio } \rho_{\mathrm{lx}}, \%\end{array}$ & $\mathrm{~A}_{\mathrm{sy}}, \mathrm{mm}^{2}$ & $\begin{array}{l}\text { reinforcement } \\
\text { ratio } \rho_{l y}, \%\end{array}$ \\
\hline I & $\begin{array}{l}\mathrm{P} 1-1 \\
\mathrm{P} 1-2\end{array}$ & \multirow{3}{*}{$500 \times 500 \times 70$} & 339 & 0,97 & 58,9 & 0,16 \\
\hline ॥ & $\begin{array}{l}\text { P2-1 } \\
\text { P2-2 }\end{array}$ & & 339 & 0,97 & 339 & 0,97 \\
\hline III & P3-1 & & 58,9 & 0,16 & 58,9 & 0,16 \\
\hline
\end{tabular}

Table 1

Geometry and reinforcement characteristics of specimens

$A_{s x}$ - reinforcement area in the $x$-direction; $A_{s y}$ - reinforcement area in the $y$-direction. 
Fig. 3

The view of specimen before (a) and after (b) casting.

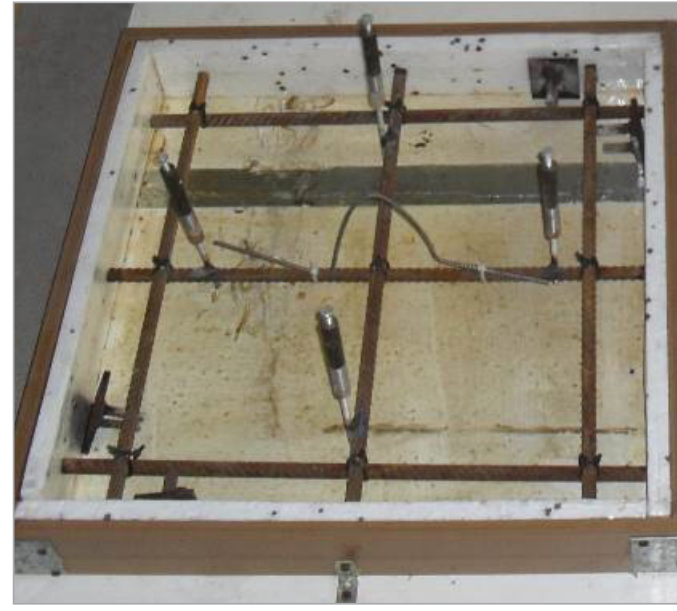

a

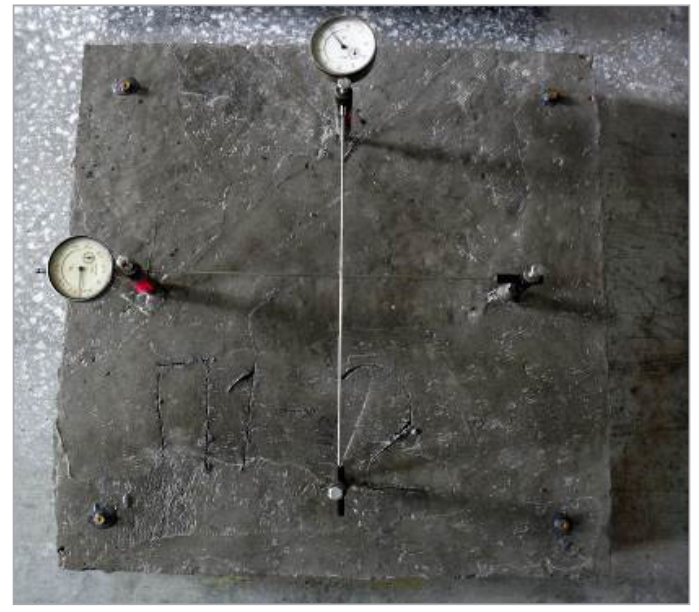

b

The expansive cement was prepared in laboratory environment and consisted of the following components by weight: Portland cement CEM I 42,5R - 74\%; high-alumina cement (HAC) - 14\%; gypsum $-12 \%$.

The expansive concrete mix composition per $1 \mathrm{~m}^{3}$ was as follows: expansive cement - 500kg; fine aggregate - 750kg; coarse aggregate - 1150kg; water - $215 \mathrm{~kg}$. The water-to-cement ratio $(\mathrm{w} / \mathrm{c})$ was 0,43 .

For every series of specimens the individual expansive concrete mix was prepared. The self-stressing grade of the expansive concrete was controlled in accordance with STB 2101 (2011). The free strains development of every series of specimens were measured on the prismatic samples bx$\mathrm{h}=50 \times 50 \mathrm{~mm}, \mathrm{l}=200 \mathrm{~mm}$. The characteristics of the expansive concrete are listed in the Table 2.

After demolding at an expansive concrete age of one day, the specimens were cured up to 28 days under moisture conditions.

Table 2

Characteristics of the expansive concrete

\begin{tabular}{c|c|c|c}
\hline series & $\begin{array}{c}\text { free strain at the concrete } \\
\text { expansion stabilization } \varepsilon_{c f}, \%\end{array}$ & $\begin{array}{c}\text { young's modulus at } 28 \text { days } \\
\text { age } E_{c m, 28}, \mathrm{GPa}\end{array}$ & $\begin{array}{c}\text { self-stressing grade at the concrete } \\
\text { expansion stabilization } f_{\text {cedd }}, \mathrm{MPa}\end{array}$ \\
\hline I & 0,117 & 42,66 & 1,4 \\
\hline$I I$ & 0,437 & 23,1 & 2,4 \\
\hline$I I I$ & 0,334 & 33,3 & 2,1 \\
\hline
\end{tabular}

The restrained expansion strains and corresponding self-stresses experimental data of plane specimens in the principal axes directions from one day to the expansive concrete stabilization along with those calculated according to the proposed model and the model described in the work Ito et al. (2004) are presented in the Fig. 4-6.

As could be seen from the Fig. 4-6, providing the low restraint level equals $\rho_{l}=0,16 \%$ the restrained expansion strains values calculated both according to the proposed model and design model Ito et al. (2004) have the similar meaning during the whole period of the expansive concrete stabilization (series I, direction $y$; series III, directions $x$ and $y$ ). Simultaneously, providing the high restraint level equals $\rho_{l}=0,97 \%$ corresponding data have the similar meaning only within fourdays initial period of stabilization. But at the end of the expansion concrete stabilization period the divergence of calculated restrained strains values extends to $40 \%$ (series II) and $26 \%$ (series I, di- 
rection $x$ ). At the same time in the case of nonsymmetrical restraint conditions in the direction with the low restraint level equals $\rho_{l}=0,16 \%$ the self-stresses calculated both according to the proposed model and design model Ito et al. (2004) have the divergence up to $40 \%$ (series I, direction $y$ ). This result is explained by the influence of the restraint in the perpendicular direction.

Comparing both experimental and calculated data of the restrained expansion strains and corresponding self-stresses it should be pointed out that values defined according to the proposed model have more similar meaning to corresponding experimental data over the whole expansive concrete stabilization period.

As with the elements under uniaxial restraint conditions (Semianiuk et al. 2017) in the case of twoway restraint conditions failing the addition cumulative force the wide disagreement has appeared

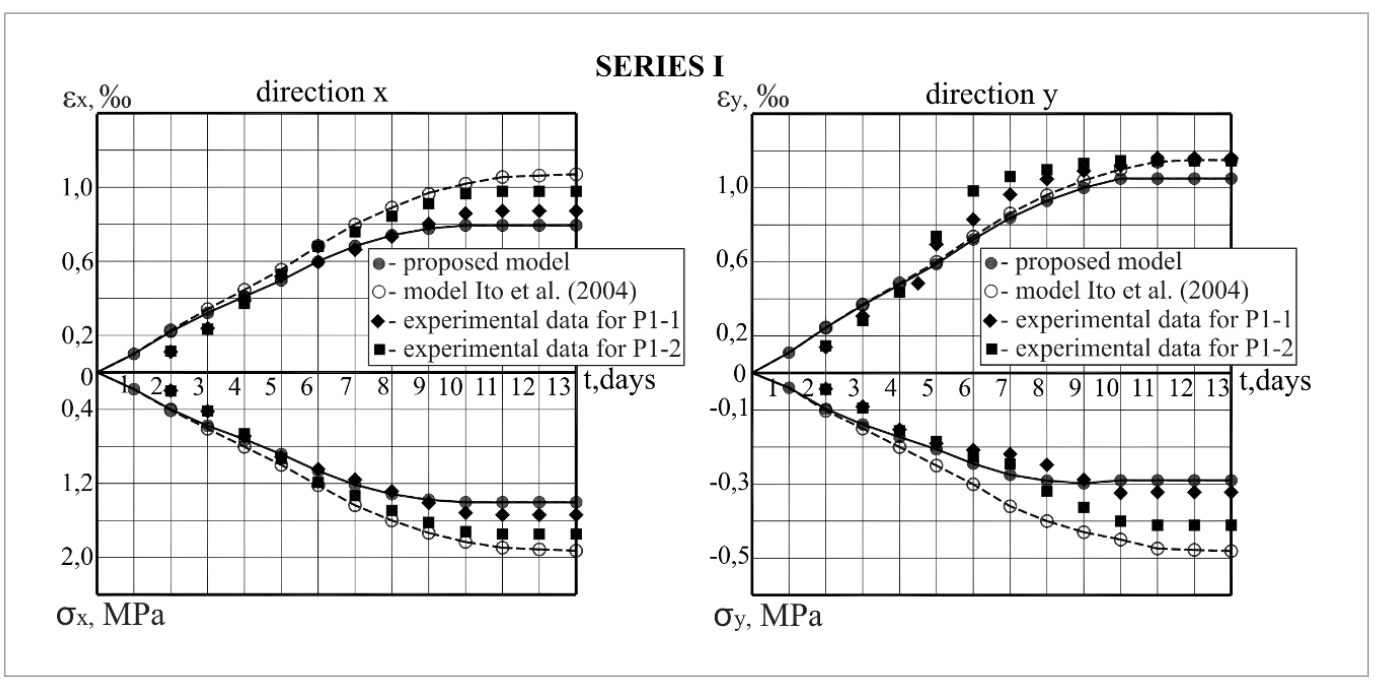

\section{SERIES II}

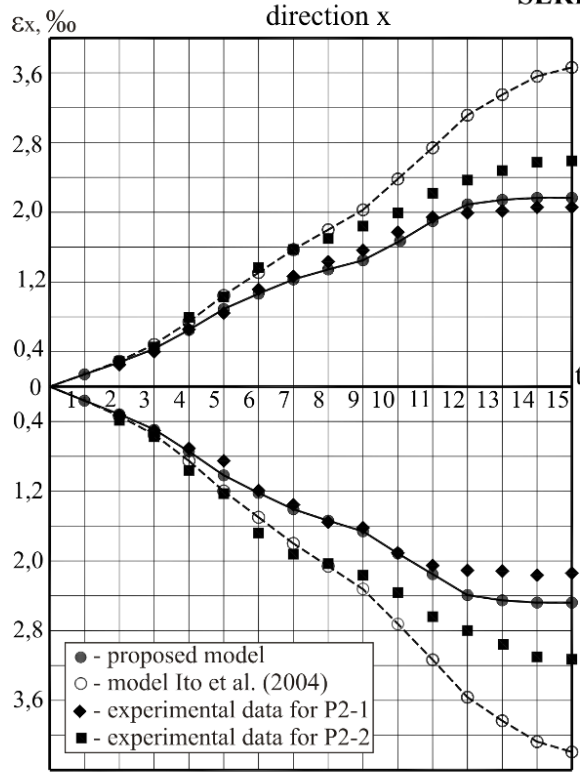

$\sigma_{\mathrm{x}}, \mathrm{MPa}$

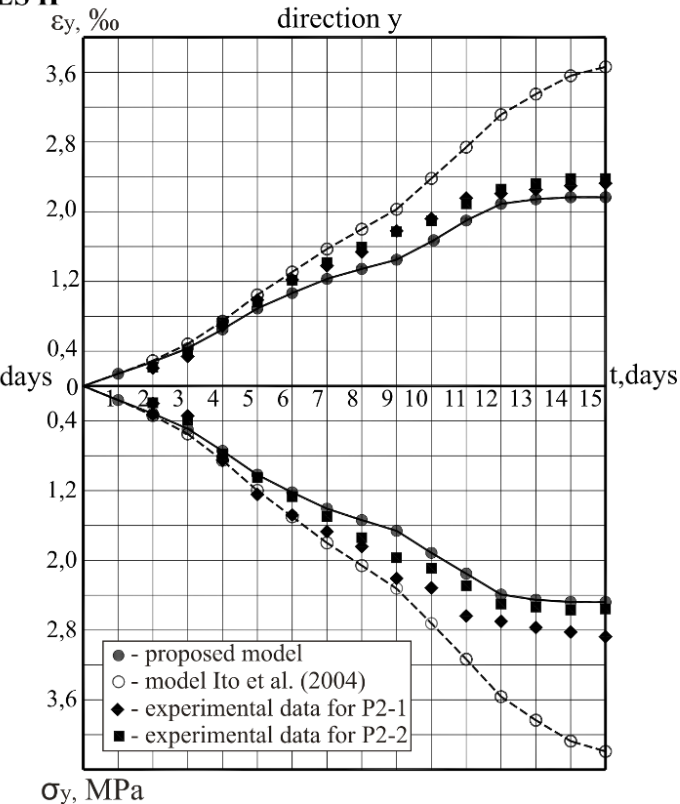

Fig. 4

The restrained expansion strains and self-stresses in the principal axes directions for the series I

Fig. 5

The restrained expansion strains and self-stresses in the principal axes directions for the series I| 
Fig. 6

The restrained expansion strains and self-stresses in the principal axes directions for the series III

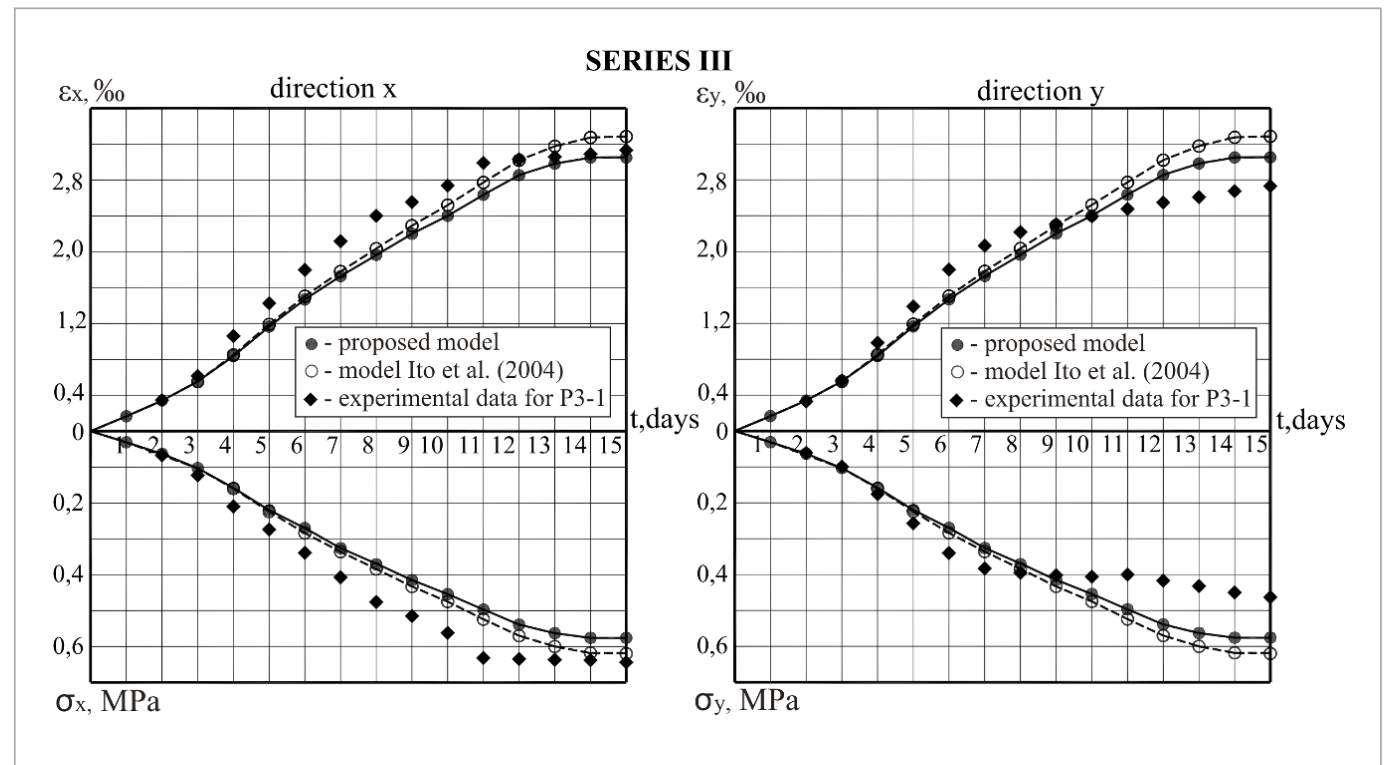

between the experimental and calculated according to the model Ito et al. (2004) restrained expansion strains and corresponding self-stresses values. This divergence has especially observed for series II providing the high restraint level $\left(\rho_{l}=0,97 \%\right)$ and high self-stressing grade of the expansive concrete $\left(f_{\text {ce.d }}=2,4 \mathrm{MPa}\right)$.

The comparison of the final restrained expansion strains values at the end of the expansion concrete stabilization period defined according to the available design models and corresponding experimental data for every series of plane specimens is shown in the Table 3.

\section{Table 3}

The restrained expansion strains values of the plane specimens at the end of the expansive concrete stabilization

\begin{tabular}{|c|c|c|c|c|c|c|c|c|c|c|}
\hline \multicolumn{11}{|c|}{ calculated restrained expansion strains $\varepsilon_{s}^{\text {calc }}$} \\
\hline \multirow{2}{*}{ design model } & \multicolumn{4}{|c|}{$\begin{array}{c}\text { series I } \\
\rho_{\mathrm{lx}}=0,97 \%, \rho_{\mathrm{ly}}=0,16 \%\end{array}$} & \multicolumn{4}{|c|}{$\begin{array}{c}\text { series II } \\
\rho_{\mathrm{lx}}=0,97 \%, \rho_{\mathrm{ly}}=0,97 \%\end{array}$} & \multicolumn{2}{|c|}{$\begin{array}{c}\text { series III } \\
\rho_{\mathrm{lx}}=0,16 \%, \rho_{\mathrm{ly}}=0,16 \%\end{array}$} \\
\hline & \multicolumn{2}{|c|}{$\varepsilon_{s, x}^{c a l c}, \%$} & \multicolumn{2}{|c|}{$\varepsilon_{s, y}^{c a l c}, \%$} & \multicolumn{2}{|c|}{$\varepsilon_{s, x}^{c a l c}, \%$} & \multicolumn{2}{|c|}{$\varepsilon_{s, y}^{c a l c}, \%$} & $\varepsilon_{s, x}^{c a l c}, \%$ & $\varepsilon_{s, y}^{\text {calc }}, \%$ \\
\hline proposed model & \multicolumn{2}{|c|}{0,794} & \multicolumn{2}{|c|}{1,054} & \multicolumn{2}{|c|}{2,166} & \multicolumn{2}{|c|}{2,166} & 3,050 & 3,050 \\
\hline model 1 (TCP Codes 2010) & \multicolumn{2}{|c|}{0,860} & \multicolumn{2}{|c|}{3,070} & \multicolumn{2}{|c|}{1,470} & \multicolumn{2}{|c|}{1,470} & 4,610 & 4,610 \\
\hline model 2 (Marchuk 2002) & \multicolumn{2}{|c|}{0,792} & \multicolumn{2}{|c|}{2,850} & \multicolumn{2}{|c|}{1,240} & \multicolumn{2}{|c|}{1,240} & 3,793 & 3,793 \\
\hline \multirow[t]{2}{*}{ model 5 (Ito et al. 2004) } & \multicolumn{2}{|c|}{1,071} & \multicolumn{2}{|c|}{1,160} & \multicolumn{2}{|c|}{3,662} & \multicolumn{2}{|c|}{3,662} & 3,284 & 3,284 \\
\hline & \multicolumn{2}{|c|}{$\varepsilon_{s, x}^{\exp }, \% 0$} & \multicolumn{2}{|c|}{$\varepsilon_{s, y}^{\exp }, \% 0$} & \multicolumn{2}{|c|}{$\varepsilon_{s, x}^{\exp }, \% 0$} & \multicolumn{2}{|c|}{$\varepsilon_{s, y}^{\exp }, \% 0$} & $\varepsilon_{s, x}^{\exp }, \% 0$ & $\varepsilon_{s, y}^{\exp }, \% 0$ \\
\hline \multirow[t]{2}{*}{ experimental data $\varepsilon_{s}^{\exp }$} & $P 1-1$ & $\mathrm{P} 1-2$ & $P 1-1$ & $\mathrm{P} 1-2$ & P2-1 & P2-2 & P2-1 & P2-2 & P3-1 & P3-1 \\
\hline & 0,872 & 0,978 & 1,161 & 1,146 & 2,058 & 2,589 & 2,327 & 2,381 & 3,132 & 2,731 \\
\hline design model & \multicolumn{10}{|c|}{$\varepsilon_{s}^{\exp } / \varepsilon_{s}^{c a l c}$} \\
\hline proposed model & 1,098 & 1,230 & 1,101 & 1,087 & 0,950 & 1,195 & 1,074 & 1,099 & 1,027 & 0,895 \\
\hline model 1 (TCP Codes 2010) & 1,014 & 1,130 & 0,378 & 0,373 & 1,400 & 1,761 & 1,583 & 1,619 & 0,679 & 0,592 \\
\hline model 2 (Marchuk 2002) & 1,101 & 1,230 & 0,407 & 0,402 & 1,660 & 2,088 & 1,876 & 1,920 & 0,825 & 0,720 \\
\hline model 5 (Ito et al. 2004) & 0,814 & 0,913 & 1,000 & 0,987 & 0,562 & 0,707 & 0,635 & 0,650 & 0,953 & 0,831 \\
\hline
\end{tabular}


As follows from the Table 3 the restrained expansion strains values calculated according to the models 1 (TCP Codes 2010) and 2 (Marchuk 2002) differ considerably from the corresponding experimental data both towards overestimation (series I, III) and underestimation (series II). Whereas the data of proposed model represent a good agreement with the corresponding experimental values (from $2,6 \%$ to $18,6 \%$ ).

1 A design model for the restrained expansion strains defining under two-way restraint conditions is presented. This model is based on the modified early age strain development model (MSDM) for the elements under uniaxial restraint conditions (Tur and Semianiuk 2016, Semianiuk et al. 2017).

2 Having a good agreement with the experimental data, the proposed design model is adequate enough for the restraint expansion strains estimation under two-way restraint conditions from the early age period to the expansion concrete stabilization. The experimental and calculated in accordance with the proposed model restrained expansion strains and corresponding self-stresses values have the similar meaning over the whole expansion concrete stabilization period (maximum divergence of values equals 22\%). At the same time the comparison of the experimental restrained expansion strains values and those calculated according to the available design models (model 1 TCP Codes (2010), model 2 Marchuk (2002), model 5 Ito et al. (2004), proposed model) demonstrates a good agreement of the proposed model data with the corresponding experimental data (maximum divergence of values equals 18,6\%).

3 The main advantage of proposed design model is the consideration of the actual curing 3 conditions of the expansive concrete specimens such as temperature, Young's modulus of the expansive concrete at given time interval and real free expansion strains development law of the expansive concrete from the early age to the end of stabilization period.

According to the proposed model the restrained expansion strains in the case of different 4 reinforcement ratio in the principal axes directions might be estimated.

Byfors J. Plane concrete at early ages. Stockholm, 1980.

CEN, TC250, EN 1992-1 Eurocode 2: Design of concrete structures - Part 1-1: General rules and rules for buildings, 2004. doi: 9780580737527.

De Schutter G., Taerwe L. Degree of hydration-based description of mechanical properties of early age concrete. Materials and Structures, July 1996; 29 : 335-344. https://doi.org/10.1007/BF02486341

Ito H., Maruyama I., Tanimura M., Sato R. Early age deformation and resultant induced stress in expansive high strength concrete. Journal of Advanced Concrete Technology, 2004; 2(2): 155-174. https:// doi.org/10.3151/jact.2.155

Fib Model Code 2010, Vol. 1, Federal Institute of Technology Lausanne - EPFL, Lausanne, March 2010.

Litver S., Petukhov A. Исследования и применение напрягающего бетона и самонапряженных конструкций [Self-stress under biaxial restraint conditions] / Сб. тр.: Исследования и применение напрягающего бетона и самонапряженных конструкций, под науч. ред. В. В. Михайлова. Москва: НИИЖБ; 1984: 67-78.

Litver S., Sabajeva N. Сравнительная оценка самонапряжения бетонов при одно- и двухосном ограничении деформаций расширения с учетом потерь от усадки [Comparative appraisal of self-stress of concretes under uniaxial and biaxial restraint conditions with taking into account the shrinkage losses] / С6. тр.: Исследования и применение напрягающего бетона и самонапряженных конструкций, под науч. ред. В. В. Михайлова. Москва: НИИЖБ; 1984: 52-61.

Marchuk V. Деформации и собственные напряжения несимметрично двухосно армированных плоских элементов из напрягающего бетона на стадии его расширения [Self-stressing of selfstressed concrete structures in conditions for plane limitation of expansion strain]. Дис. ... канд. техн. наук, 05.23.01. Брест; 2002.
Conclusions

\section{References}


Mikhailov V., Gershvald V. Плоские самонапряженные конструкции [Plate self-stressing structures] / С6. тр.: Исследования и применение напрягающего бетона и самонапряженных конструкций, под науч. ред. В. В. Михайлова. Москва: НИИЖБ; 1984: 62-67.

Mikhailov V., Litver S. Расширяющийся и напрягающие цементы и самонапряженные конструкции [Expansive and self-stressing cements and selfstressed reinforces structures]. Москва: Стройиздат; 1974.

Oluokun F. A., Burdette E. G., Deatherage J. H. Elastic moduli, Poisson's ratio and compressive strength relationships at early ages. ACl Material Journal, Jan.-Feb. 1991: 3-10.

Semianiuk V., Tur V., Herrador M. F., Paredes G. $M$. Early age strain and self-stresses of expansive concrete members under uniaxial restraint conditions. Construction and building materials, 2017; 131: 39-49. https://doi.org/10.1016/j.conbuildmat.2016.11.008

STB 2101-2010. Бетоны напрягающие: технические условия [Self-stressing concretes: specifications]. Минск: РУП “Стройтехнорм”, 2011.

Tanimura M., Sato R., Hiramatsu V. Serviceability performance evaluation of RC flexural members improved by using low-shrinkage high-strength concrete. Journal of Advanced Concrete Technology, 2007; 5(2): 140-160. https://doi.org/10.3151/jact.5.149

Tazawa E., Sato R., Sakai E., Miyazawa S. Work of $\mathrm{JCl}$ Committee on autogenous shrinkage. Interna- tional RILEM workshop on shrinkage of concrete, 16-17 October 2000: 21-40.

ТСР 45-5.03-158-2009. Бетонные и железобетонные конструкции из напрягающего бетона: правила проектирования [Concrete and reinforced concrete structures from self-stressing concrete: design rules]. Минск: Минстройархитектуры; 2010.

Truman K. Z., Petrushka D. J., Norman C. D. Creep, shrinkage and thermal effects on mass concrete structures. Journal of Eng. Mech., June 1991; 117(6): 1274-1288. https://doi.org/10.1061/(ASCE)07339399(1991)117:6(1274)

Tsuji Y. Methods of estimating chemical prestress and expansion distribution in expansive concrete subjected to uniaxial restraint. Concrete Library of JSCE, 1984; 3: 131-143.

Tur V., Kondratchik A., Sannikava V. Определение параметров напряженно-деформированного состояния плоских самонапряженных элементов на стадии твердения [The stress-strain parameters defining of plate self-stressed structures at curing period]. Вестник БрГТУ. Сер. Строительство и архитектура, 2016; 1(97): 70-76.

Tur V., Semianiuk V. Модель, применяемая для расчета связанных деформаций и самонапряжений в элементах из напрягающего бетона [Models for restrained strains and self-stressing stresses in the members made of expansive concrete calculation]. Вестник БрГТУ. Сер. Строительство и архитектура, 2016; 1 (97): 54-70.

\section{About the authors}

\section{VOLHA SANNIKAVA}

\section{MSc, engineer}

Brest State Technical University, Faculty of Civil Engineering, Department "Geotechnics and transport communications"

\section{Main research area}

Self-stressing concrete structures

\section{Address}

267, Moskovskaya str., 224017, Brest, Belarus Tel. +375 297255952

E-mail: volhasannikava@list.ru

\section{VICTAR TUR}

\section{Professor, DSc, PhD}

Brest State Technical University, Faculty of Civil Engineering, Department "Technology of concrete and building materials"

\section{Main research area}

Self-stressing concrete structures, reliability of building structures

\section{Address}

267, Moskovskaya str., 224017, Brest, Belarus

Tel. +375336729404

E-mail:profturvic@gmail.com 